\title{
Double package of atopic dermatitis in Munich
}

\section{Abstracts of New Trends in Allergy VII and 6th Georg Rajka Symposium on Atopic Dermatitis}

W elcome to a unique event in $\mathrm{Mu}-$ nich, 22-24 July 2010, with the combined international symposium "New Trends in Allergy VII" and "6th Georg Rajka Symposium on Atopic Dermatitis". Both events have a long standing tradition going back over 30 years.

The first symposium "New Trends in Allergy" had a successful start in 1980 in Munich. The organisers resisted the temptation to repeat it in an annual interval, because they had the feeling that really new things do not happen regularly every year; this led to the five-year rhythm which has been kept ever since in Munich, Hamburg, Davos and now back in Munich. The essence of this symposium is that invited speakers from various fields, both in basic science and in clinical research, come together not only presenting their newest data but giving a brief outlook into the future, what might be expected in the coming years from their point of view.

The tradition of the "Symposium on Atopic Dermatitis" goes back to Norway, where Georg Rajka started this unusual series in variable intervals in Oslo, in Bergen, and in the fjords, bringing together all the experts interested in this disease. These symposia were so success- ful that it was decided to continue the tradition and name them after the founder Professor Georg Rajka, who will be present in Munich and give us an introductory remark. The Rajka Symposia have been held since 1996 in Aarhus, Rome, Portland, Bordeaux and Kyoto and now in Munich. It is a unique chance that both events are joined together since atopic eczema represents one of the greatest challenges in clinical allergy.

The faculty consists of internationally known experts from all over the world. The program is highlighted by main topics, epidemiology, environmental aspects, molecular genetics, asthma, anaphylaxis, atopic eczema and general allergy management regarding prevention and therapy. Free communications will be presented as posters. On the following 32 pages you will find abstracts of both, invited presentations and posters.

Another tradition of "New Trends in Allergy" is that on the occasion of the "Bavarian evening", a musical will be performed by the organising crew, featuring in a humoristic way the dilemmas of allergy in research and clinical practice. Don't miss this event on Friday, 23 July 2010 in the famous $\mathrm{Mu}$ nich Löwenbräukeller.

\begin{tabular}{llc} 
Contents & & Number \\
\hline Oral presentations & $01-017$ & 310 \\
$\quad$ Special workshop "Atopic eczema in dogs" & 315 \\
Poster & $018-023$ & \\
Epidemiology, environment and allergy & P1.1-P1.19 & 318 \\
\hline Basic immunology and genetics & P2.1-P2.15 & 324 \\
Clinical allergy & P3.1-P3.14 & 330 \\
\hline Psyche and itch & P4.1-P4.5 & 334 \\
\hline Prevention and therapy & P5.1-P5.14 & 336 \\
\hline Index of authors & & 341
\end{tabular}

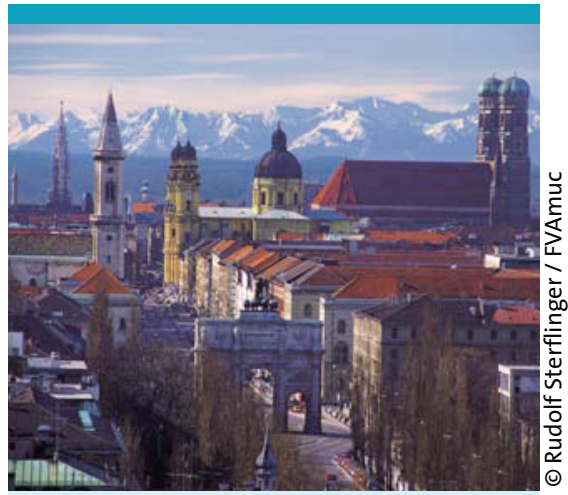

Conference at a glance

Date

22-24 July 2010

Venue

The Westin Grand München

Arabellapark

Arabellastraße 6

81925 Munich

Chairpersons

Prof. Dr. med. Dr. phil. Johannes Ring

Prof. Dr. Ulf Darsow

Prof. Dr. Heidrun Behrendt

Organisation and Registration

Eva Burk, Katharina Heinke

INTERPLAN Congress, Meeting \& Event

Management AG

Albert-Roßhaupter-Straße 65, 81369

Munich, Germany

Fon: (+49 89) $548234-73$

Fax: (+49 89) $548234-42$

E-mail: trends1o@interplan.de

Web: www.new-trends-allergy.de

On behalf of the organising committee we cordially welcome you to Munich wishing you an interesting and stimulating congress and a chance to meet old and make new friends!

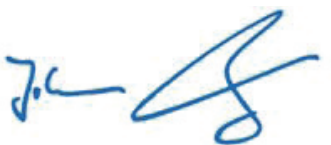

Prof. Dr. Johannes Ring
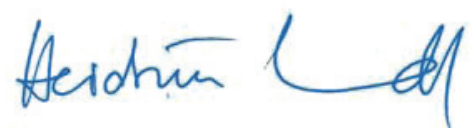

Prof. Dr. Heidrun Behrendt

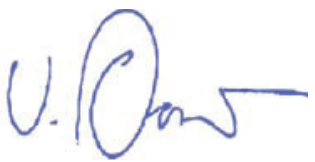

Prof. Dr. Ulf Darsow 